\title{
The relationship between the physical activity efficacy and physical activity of the middle school students
}

\author{
Alpkaya U. ${ }^{\mathrm{ABCDE}}$ \\ Faculty of Sport Sciences, Physical Education and Sport Teaching, Marmara University, İstanbul, Turkey
}

Authors' Contribution: A - Study design; B - Data collection; C - Statistical analysis; D - Manuscript Preparation; E - Funds Collection

\begin{abstract}
Purpose: $\quad$ The purpose of this study is to determine the physical activity efficacy and physical activity of the middle school students, according to gender and to analyze the relationship between them.

Material: $\quad$ The study group consisted of a total of 701 students from three public secondary schools, 343 of whom were female and 358 were male students. In order to determine the physical activity efficacy of the students, the Physical Activity Efficacy Scale was used, while the Physical Activity Questionnaire for Older Children was used for establishing the level of physical activity. In evaluating the data, descriptive statistics, independent t-test, Pearson correlation tests were used as statistical methods.

Results: $\quad$ According to the data obtained by the study, the students' physical activity efficacy was found to be good, with no difference between the females and the males ( $p>0.05)$. The students' physical activity level was average, while the males were found to be physically more active than the females $(p<0.05)$. A positive correlation was found between the physical activity efficacy and the physical activity of the students $(p<0.05)$.

Conclusions: According to the findings of this study, physical activities should be increased during the time of the middle school, which is a part of the period of adolescence. Besides, in order to enhance their physical activity efficacy, the adolescents should be provided with physical activity environments.

Keywords: $\quad$ adolescence, physical activity efficacy, physical activity, middle school, gender.
\end{abstract}

\section{Introduction}

Physical activity is defined as any movement of the body produced by the skeletal muscles resulting in energy expenditure [1]. The World Health Organization [2] recommends that children and adolescents aged 6-17 years engage in at least 60 minutes of moderate to vigorous physical activity daily. Environmental factors such as increasing urbanization, intense traffic, pollution, increasing concrete constructions, lack of parks, sports and recreational facilities have decreased participation in physical activities [3]. In parallel to these challenges, increase in the consumption of high-calorie foods, use of digital technology and adoption of a sedentary life style with ageing, physical activity and its enhancement in the children and adolescents have become more important [4, 5].

Many studies conducted state that physical activity strengthen bones and muscles, improve social and psychological health, and enhance fitness level [6, 7]. Decrease in physical activity in children and adolescents in recent years has increased the risk of developing many chronic diseases, particularly obesity in early ages $[8,9]$. On the other hand, physical inactivity is related to numerous health problems including increased risk of heart disease, hypertension, and stroke [10, 11]. For this reason, increasing physical activity and reducing sedentariness are seen among the essential strategies for preventing many diseases, which either pertain to childhood or start developing during childhood [5, 6].

Several studies indicate that participation in physical activities diminishes with age, especially in high school years [12, 13]. World Health Organization [2] has stated (c) Alpkaya U., 2019

doi:10.15561/18189172.2019.0202 that $77-85 \%$ of the European adolescents do not reach 60 minutes of moderate to vigorous activity daily. Dumith et al. [14] observed that there has been a net increase in the sedentary time during the early adolescence and a $7 \%$ annual decrease in physical activity during the adolescence in the developing countries. A decrease in the physical activity is seen from the childhood to the end of adolescence [15]. Troiano et al. [16] have stated that the students' physical activity rate of $100 \%$ in the primary school drops to $30 \%$ when they are in the high school.

Apart from the external factors that affect the participation in physical activities, the individual's state of self-efficacy is also an important determinant in such participation $[17,18]$. Self-efficacy is the main component of Bandura's [19] social cognitive theory and an important individual determinant of human behavior. According to the theory of self-efficacy, the confidence in an individual's belief in his capabilities to realize a behavior also affects the direction, intensity, and permanence of a behavior $[20,21]$. The higher the confidence is, the more the desire is to struggle with the challenges. This critical belief constitutes the basis of human motivation and action [22]. Bandura [23] says that an individual's targets will be as high and his desire to do physical activity will be as strong as his self-perception of his self-efficacy for physical activity. Many studies indicate that self-efficacy is one of the most important determinants of the physical activity $[17,24,25]$. McAuley et al. [26] argue that self-efficacy is important during the early stages of the participation in the physical activities, when the individual faces difficulty due to some obstacles such as fatigue or lack of time. Furthermore, people with higher self-confidence in their physical abilities are more prone to take part 
in physical activities. Similarly, it is also stated that as people participate in exercise programs more, they reach a higher level of general self-efficacy in time [17, 27].

It would be reasonable to suggest that if people have a high self-efficacy about their physical abilities with their experience of physical activity, it is more likely that they will embrace physical exercise [28]. Stutts [29] has argued that self-efficacy is an important sign of regular physical activity, and therefore some interventions should be designed in order to help people reach higher degrees of self-efficacy. Gao et al. [30], in their study on 207 middle school students, have found that self-efficacy affects the participation in physical activities in physical education courses at a rate of $54 \%$. While some studies conducted found no correlation between physical activity efficacy and physical activity [31-33], some others found a positive correlation between them [24, 34-36]. Van et al. [37] have found a positive correlation between selfefficacy and physical activity for adolescents between the ages of 13 and 18. On the other hand, Sallis et al. [38] have reached different conclusions for the same age group.

The inconsistent results for the relationship between physical activity efficacy and physical activity among adolescents may be due to a lack of consistent or standard measurement across studies [32, 39, 40]. Adolescent physical activity, especially in Turkey, is recently being considered a crucial factor in the health status of people, and has become an important public health and social issue in society. Moreover, research about relationship between self-efficacy and physical activity is limited. Our study aim at determining the levels of physical activity for middle school students and to find out whether the physical self-efficacy of the students affect their participation in physical activities.

\section{Material and Methods}

\section{Participants.}

Our study group consisted of a total of 701 students of three public middle schools (age; $12.60 \pm 1.07$ year) from İstanbul province - Turkey, 343 of whom were female (age; $12.54 \pm 1.03$ year) and 358 were male (age;12.66 \pm 1.09 year) students.

\section{Procedure}

The study was carried out in April, 2018. Before the study, the school administrations and the parents were informed and their consents were obtained. This study was conducted in accordance with the Declaration of Helsinki. The students were informed about the scales previous to the study and their questions were answered on the spot. During the study, the students filled in the physical activity scale on the first day, and the physical efficacy was filled in test on the second day. Each visit took approximately 20 minutes and was conducted during class time. The scales filled in by the students were controlled by the researchers, and the ones filled incorrectly or incomplete were left out of the research. All the scales were implemented by the researcher.

Physical Activity scale

In order to determine the physical activity level of the students, the Physical Activity Questionnaire for Older Children (PAQ-C) developed by Kowalski et al. [41] was used. The scale's validity and reliability for Turkish people were tested by Sert and Temel [42], and the scale, made up of 10 questions, was a 5-point Likert-type scale, the reliability of which was .74 . The scale measures the level of physical activity done by the individual during the last seven days. The tenth question of the questionnaire asked whether the individual had any health problems during the last seven days that prevented them from doing physical activity. Those who said yes to this question were not included, while those answering this question positively, 28 for this study, were not included in the research. The lowest score that can be obtained from the scale is 9, whereas the highest is 45 . Cronbach's Alpha reliability coefficient of the scale for this sample is 0.79 .

Physical Activity Efficacy Scale

Developed by Campbell et al. [20] and adapted to the Turkish society by Saygin et al. [43], Physical Activity Efficacy Scale (PAES) was used. The scale was made up of 5 dimensions and 26 items, and the reliability co-efficient of the scale was .40-.92. The scale form consists of two sections. The first section consists of demographic information, whereas the second section asks the individuals about their levels of self-confidence about their participation in physical activities done five areas of physical activity. The scale was a 10-point Likerttype scale $(0=$ No confidence at all, and $100=$ complete confidence). Total average score is calculated based on answers given to items ranging from 0 to 100 . Higher scores mean higher physical activity efficacy. Cronbach's alpha reliability coefficient of the scale for this sample is .90. A physical activity efficacy score for each participant was obtained by averaging the five items on this scale.

\section{Statistical analysis}

All statistical methods applied in this study were conducted using the SPSS 18.0. For the analysis of the data, first normal distribution test was done. Since the skewness-kurtosis value was between $-1.5+1.5$, it was considered to be a normal distribution [44]. Descriptive statistics (means and standard deviations) were used to summarize the participants' characteristics. Independent Samples $t$ test was used to analyze the difference in physical activity level and physical activity efficacy between male and female students. Pearson Correlations test was used to analyze the correlation between physical activity and physical activity efficacy. The level of significance was set at $\mathrm{p}<0.05$.

\section{Results}

Descriptive statistics are presented on Table 1. Values for the students' age, height, and weight are as seen on Table 1. Physical activity efficacy scores for the whole group is $73.99 \pm 17.11$, whereas it is $73.28 \pm 16.42$ for the females and $74.74 \pm 17.60$ for the males. Therefore, the physical activity efficacy of the students can be said to be good. The physical activity level score for the whole group is $27.84 \pm 6.63$, and $26.85 \pm 6.78$ for the females and $28.78 \pm 6.35$ for the males. Therefore, the physical activity 
Table 1. Descriptive statistics of students

\begin{tabular}{|c|c|c|c|c|c|c|}
\hline \multirow[t]{2}{*}{ Variables } & \multicolumn{2}{|c|}{$\begin{array}{l}\text { Whole group } \\
n=701\end{array}$} & \multicolumn{2}{|l|}{$\begin{array}{l}\text { Female } \\
n=343\end{array}$} & \multicolumn{2}{|l|}{$\begin{array}{l}\text { Male } \\
n=358\end{array}$} \\
\hline & Mean & Sd & Mean & Sd & Mean & SD \\
\hline Age (year) & 12.60 & 1.07 & 12.54 & 1.03 & 12.66 & 1.09 \\
\hline Height (cm) & 156.09 & 10.11 & 155.48 & 8.71 & 156.68 & 11.27 \\
\hline Weight (kg) & 51.83 & 11.48 & 50.83 & 9.43 & 52.78 & 13.09 \\
\hline Physical Activity Efficacy (point) & 73.99 & 17.01 & 73.28 & 17.60 & 74.74 & 16.42 \\
\hline Physical Activity (point) & 27.84 & 6.63 & 26.85 & 6.78 & 28.78 & 6.35 \\
\hline
\end{tabular}

Table 2. Comparison of the physical activity efficacy and physical activity level of the students according to gender

\begin{tabular}{lllllll}
\hline Variables & Female & & Male & & \\
& Mean & Sd & Mean & Sd & $t$ & $p$ \\
\hline Physical Activity Efficacy & 73.28 & 17.60 & 74.74 & 16.42 & 1.135 & .257 \\
Physical Activity & 26.85 & 6.78 & 28.78 & 6.35 & -3.871 & .000 \\
\hline
\end{tabular}

$p<0.05$

Table 3. Correlation between physical activity efficacy and physical activity

\begin{tabular}{|c|c|c|c|}
\hline \multicolumn{2}{|c|}{ Variables } & \multirow{2}{*}{$\begin{array}{l}\text { Physical Activity } \\
.168^{* *}\end{array}$} & \multirow[t]{2}{*}{ Physical Activity Efficacy } \\
\hline Whole Group & Physical Activity Efficacy & & \\
\hline$(n=701)$ & Physical Activity & & 1 \\
\hline Female & Physical Activity Efficacy & $.144^{* *}$ & \\
\hline$(n=343)$ & Physical Activity & & 1 \\
\hline Male & Physical Activity Efficacy & $.212^{* *}$ & \\
\hline$(n=358)$ & Physical Activity & & 1 \\
\hline
\end{tabular}

${ }^{*} p<0.05,{ }^{* *} p<0.01$

level of the students can be said to be at an average level.

There is no statistically difference between the females and males in terms of their physical activity efficacy $(p>0.05)$. Both the females and males can be said to have enough motivation and physical capacity to do physical activity. In terms of levels of physical activity, there is a significant difference between the females and the males $(p<0.01)$. The males are more physically active than the females.

For the whole group, there is a significant correlation between the physical activity and the physical activity efficacy of the students $(\mathrm{p}<0.01 ; \mathrm{r}=.168)$. When the scores are analyzed with reference to gender difference, there is again a correlation between the physical activity and the physical activity efficacy both for the females $(p<0.01$; $\mathrm{r}=.144)$ and the males $(\mathrm{p}<0.01 ; \mathrm{r}=.212)$. We can say that as the physical efficacy increases, so does physical activity.

\section{Discussion}

According to the findings of the study, physical activity efficacy scores both for the whole group, and for the females and the males separately were found high. We can say that the students were self-confident in participating physical activities. Physical efficacy means one's belief in his capacity to master and carry out physical activities $[45,46]$. It has been reported that strong physical activity self-efficacy perception is linked with better performance, showing more effort for mastery, a higher level of physical activity and a longer perseverance in the face of challenges [47]. When the physical activity efficacy of the students was compared in terms of gender, a statistically significant difference was not found $(\mathrm{p}>0.05)$. According to the findings of the study, we can say that there is no difference between the females and the males in this respect. When the literature is examined, it is seen that the physical activity efficacy of the males is higher than that of the females [48, 49-51]. Although the results in this study were not statistically significant, still the average of the scores were in favor of the males. When the physical activity scores of the students participating in the study are examined, it is seen that they are active at a moderate level. This level of physical activity is not seen sufficient in adolescents $[1,2]$.

In literature, many studies have pointed at the benefits of a physically active life style on health during childhood and adolescence. [52-54]. Physical inactivity, being overweight and obesity are known to increase the risks of cardiovascular diseases, cancer and osteoporosis at later ages $[11,53,55]$. Therefore, it would be proper to increase the physical activity during the middle school period, which is a part of the adolescence. When the students' physical activity scores are compared with reference to gender, the physical activity levels of the males are found to be higher than those of the females $(\mathrm{P}<0.05)$. These 
findings show parallelism with other studies [7, 56-58]. The females' being less active during adolescence is accounted for with reference to that they receive less social support than the males for taking part in physical activities, that the like physical activity less $[59,60]$ and that they chronologically mature faster than the males, which might distract them from physical activities [61].

A significant correlation was found between the physical efficacy and physical activity for the whole study group $(\mathrm{p}<0.01)$. It can be said that physical efficacy increases as the physical activity does. According to the findings of the study, increase in physical activity and the physical efficacy affect each other positively. However, physical activity levels of the students were found to be average, although their physical activity self-efficacy levels were high, which is odd. Physical efficacy and participation in physical activities have been studied before, and a strong correlation has been found between them $[25,40,49,50]$.

Self-efficacy theory suggests that those who are confident in their abilities to execute a behavior, even when confronted with barriers, are more likely to engage in that behavior [21]. Hutchins et al. [51] has argued that the individuals with higher levels of self-efficacy are not only more effective in physical activities, but th ey are also more likely to be active for longer. This study began with the hypothesis that the physical activity efficacy scores and physical activity score would be at a similar level. However, the results of this study point at a high physical activity efficacy but an average level of physical activity. Therefore, in this study we can say, as in the argument by Hutchins et al. [51], that the level of physical activity was not very much affected by the physical efficacy. According to the data by Nutrition and Health Research, in Turkish society $52.7 \%$ of the children aged $9-11,56.2 \%$ of the children aged $12-14$ and $57.8 \%$ of the adolescents aged 15-18 do not take part in any physical activity [62]. Therefore, it can be said that the findings of this study are similar in that the students are active at an average level. The studies conducted have emphasized the benefits of the physically active life style during childhood and adolescence on health $[6,7]$. It can also be considered that the students in our study group did not make time for physical activity, since they were not guided by their parents or environment, and they were not informed about the health benefits of physical activity. However, their physical activity efficacy's being high can be accounted for by saying that they have confidence in their capacity for doing physical activity but do not care much about doing it.

In recent years, there has been a decrease in children's participation in physical activities because of the increase in sedentary activities such as watching TV/video and using computers $[12,13,16]$. However, for the health of both children and the society it is important to support the children for an active life style in the long run. Physical activity not only protects individuals from many chronic diseases such as obesity, cardiovascular diseases and cancer, it also has many psycho-social benefits such as boosting self-confidence, self-esteem, and academic achievement and alleviating the symptoms of depression $[5,63]$. For these reasons, the society should promote and encourage forming a more active life style and adopting a habit of doing regular exercise, starting with the childhood period $[9,64,65]$. Increasing the variety of the physical activities and decreasing their difficulty can be a solution. Thus, the individuals would enjoy the activity as much as they could do it; and this would also ease the transition to the activity, which is one degree heavier than the previous one. A child's environment is effective in increasing her physical activity. In other words, easy access to physical activity equipment, availability of recreational areas such as parks and gyms and having individuals doing physical activities around the student can encourage the children's and adolescents' participation in physical activities $[3,66]$.

Providing people with physical activity alternatives is reported to increase motivation and self-efficacy [51]. Shen and $\mathrm{Xu}$ [24] have concluded that a variable, both physical and psychological, affects the motivation for physical activity. For this reason, they have argued that ecological approaches taking psychological and social factors into account should be given more weight. Therefore, the findings of this study should also be evaluated within the said constraints. Firstly, the study group's being made up of three public middle schools of the same province can be considered as a constraint of the study. This study also used, while establishing the physical activity levels of the students, reports given by students themselves, and thus, we had to assume that the students answered the questionnaire truly and fairly. While evaluating the physical activity, using real physical activity patterns based on calorie expenditure would give more precise results. Differences between the findings of this study and the findings of literature in terms of some variables indicate that there should be further research on these areas. We also think that future studies need larger and various sample groups.

\section{Conclusion}

In this study, a positive correlation was found between the physical activity efficacy and the physical activity of the middle school students. However, physical activity efficacy of the students were found to be high, although their physical activity were average, which is odd. This level of physical activity is not seen sufficient in adolescents.

In order to increase physical activity and physical efficacy, sports and recreational programs that are socially fit for the physical and psychological development of all children and adolescents and that arouse their interest should be designed, and these programs should be regularly assessed.

\section{Financing}

No financial support was received for the research.

\section{Conflict of interest}

The author declare no conflict of interest. 


\section{References}

1. Ward DS, Saunders RP, Pate RR. Physical activity Interventions in Children and Adolescents. Human Kinetics US. 2007; 3-21.

2. World Health Organization. Physical Inactivity: A Global Public Health Problem. From Global Strategy on Diet, Physical activity and Health Retrieved. [Internet]. WHO; 2018. [cited 2019 Mar 22]. Available from: http://www.who. int/diet-physicalactivity-/factsheet_inactivity/en

3. Sandu P, Cherechesb RM, Baba CO, Revnic RN, Moceana F. Environmental influences on physical activity - Romanian youths' perspectives. Children and Youth Services Review, 2018; (95):71-79. https://doi.org/10.1016/j.childyouth.2018.10.020

4. Micklesfield LK, Pedro TM, Kahn K, Kinsman J, Pettifor JM, Tollman S, et al. Physical activity and sedentary behavior among adolescents in rural South Africa: Levels, patterns and correlates. BMC Public Health. 2014; 14(40): 1-10. https://doi.org/10.1186/1471-2458-14-40

5. Gopinath B, Hardy LL, Baur LA, Burlutsky G, Mitchell P. Physical activity and sedentary behaviors and health-related quality of life in adolescents. Pediatrics. 2012; 130:167-74. https://doi.org/10.1542/peds.2011-3637

6. Donnelly JE, Hillman CH, Castelli D, Etnier JL, Lee S, Tomporowski P, Lambourne K, Szabo-Reed AN. Physical Activity, Fitness, Cognitive Function, and Academic Achievement in Children: A Systematic Review. Medicine Science in Sports and Exercise. 2017;48(6): 1197-1222. https://doi.org/10.1249/MSS.0000000000000901

7. Telford RM, Telford RD, Olive LS, Cochrane T, Davey R. Why are girls less physically active than boys? findings from the look longitudinal study. PLOS ONE. 2016; (11)3: 1-11. https://doi.org/10.1371/journal.pone.0150041

8. Harding SK, Page AS, Falconer C, Cooper AR. Longitudinal changes in sedentary time and physical activity during adolescence. International Journal of Behavioral Nutrition and Physical Activity [Internet]. 2015 Dec [cited 2019 Mar 15];12(1). Available from: https://ijbnpa. biomedcentral.com/articles/10.1186/s12966-015-0204-6 https://doi.org/10.1186/s12966-015-0204-6

9. Meydanlığlu, A. Biopsychosocial benefits of physical activity in children. Psikiyatride Güncel Yaklaşımlar, 2015; 7(2): 125-135.

10.American Heart Association. (AHA) Physical activity improves quality of life. [Internet]. 2015. [cited 2019 Mar 22]. Available from: http://www.heart.org/HEARTORG/ GettingHealthy/PhysicalActivity/StartWalking/ Physicalactivity improvesquality-of-lifeUCM - 307977 Article.jsp\#.Vo7YLcYrK70

11. World Health Organization. Global Recommendations on Physical Activity for Health. Geneva: WHO Press; 2010.

12.Anderssen N, Wold B, Torsheim Y. Tracking of physical activity in adolescence. Research Quarterly for Exercise and Sport, 2013;76(2): 119-129. https://doi.org/10.1080/02701367.2005.10599274

13.Currie C, Zanotti C, Morgan A, Currie D, Looze M, Roberts C, Samdal O, et al. Social determinants of health and wellbeing among young people. Health Behaviour in School-aged Children study: International report from the 2009/2010 survey. Copenhagen: WHO Regional Office for Europe, Health Policy for Children and Adolescents; 2012.

14.Dumith SC, Gigante DP, Domingues MR, Kohl HW. Physical activity change during adolescence: a systematic review and a pooled analysis. Int J Epidemiol. 2011;40:685-698. https://doi.org/10.1093/ije/dyq272
15.McDermott RJ, Nickelson J, Baldwin JA, Bryant CA, Alfonso M, Phillips LM, et al. A community-school districtuniversity partnership for assessing physical activity of tweens. Preventing Chronic Disease, 2009; 6(1): A15.

16.Troiano RP, Berrigan D, Dodd K. W, Masse LC, Tilert T, McDowel M. Physical activity in the united states measured by accelerometer. Medicine Science in Sports Exercise, 2008; 40(1): 181-188. https://doi.org/10.1249/mss.0b013e31815a51b3

17.Ashford S, Edmunds J, French DP. What is the best way to change self-efficacy to promote lifestyle and recreational physical activity? A systematic review with meta-analysis. British journal of health psychology. 2010;15:265:-88.

18.Petosa RJ, Hortz BV, Cardina CE, Suminski R. R. Social cognitive theory variables associated with physical activity among high school students. International Journal of Sports Medicine, 2005; 26: 158-163. https://doi.org/10.1055/s-2004-821135

19.Bandura A. Social Foundations of Thought and Action: A Social Cognitive Theory. Englewood Cliffs, NJ.: PrenticeHall.; 1986.

20.Campbell N, Gray C, Foley L, Maddison R, Prapavessis H. A domain-specific approach for assessing physical activity efficacy in adolescents: From scale conception to predictive validity. Psychology of Sport and Ex., 2016; 22: 20-26. https://doi.org/10.1016/j.psychsport.2015.05.002

21.Bandura A. Self-efficacy: toward a unifying theory of behavioural change. Psychological Review, 1977;84(2): 191-215. https://doi.org/10.1037/0033-295X.84.2.191

22. Wu T, Pender N, Noureddine S. Gender differences in the psychosocial and cognitive correlates of physical activity among Taiwanese adolescents: a structural equation modeling approach. International Journal of Behavioral Medicine, 2003; 10(2): 93-105. https://doi.org/10.1207/S15327558IJBM1002 01

23. Bandura A. Health Promotion by Social Cognitive Means. Health Education \& Behavior. 2004 Apr;31(2):143-64. https://doi.org/10.1177/1090198104263660

24.Shen B, Xu C. Effects of self-efficacy, body mass, and cardiorespiratory fitness on exercise motives in Chinese college students. Journal of Physical Activity and Health, 2008; 5(5): 706-718. https://doi.org/10.1123/jpah.5.5.706

25.Kang S, Kim Y. Relationship of social norms and self-efficacy with physical activity in Korean Adolescents. Revista de Psicología del Deporte 2015; 24,(2): 305-310.

26.McAuley E, Mailey EL, Mullen SP, Szabo AN, Wójcicki TR, White SM, et al. Growth trajectories of exercise self-efficacy in older adults: Influence of measures and initial status. Health Psychology. 2011; 30:75 - 83. https://doi.org/10.1037/a0021567

27. Warner LM, Schuz B, Wolff JK, Parschau L, Wurm S, Schwarzer R. Sources of self-efficacy for physical activity. Health Psychology. 2014; 33:1298-1308. https://doi.org/10.1037/hea0000085

28. Wu TY, Robbins LB, Hsieh HF. Instrument Development and Validation of Perceived Physical Activity Self-Efficacy Scale for Adolescents. Research and Theory for Nursing Practice,2011;(25):39-54. do1:10.1891/08897182.25.1.39

29.Stutts WC. Physical activity determinants in adults: perceived benefits, barriers, and selfefficacy. Aaohn Journal. 2002; 50(11): 499-507. https://doi.org/10.1177/216507990205001106

30.Gao Z, Lee AM, Kosma M, Solmon MA. Understanding students' motivation in middle school physical education: 
examining the mediating role of self-efficacy on physical activity. International Journal of Sport Psychology, 2010; 41(3): 199-215.

31.Bungum TL, Vincent ML. Determinants of physical activity among female athletes. American Journal of Preventive Medicine, 1997; 13: 115-122. https://doi.org/10.1016/S0749-3797(18)30208-3

32.Dilorenzo T M, Stucky-Ropp RC, Van der Wal JS, Gotham HJ. Determinants of exercise among children. II. A longitudinal analysis. Preventive Medicine. 1998; 27: 470-477. https://doi.org/10.1006/pmed.1998.0307

33. Garcia AW, Broda MA. Frenn M, Coviak C, Pender NJ, Ronis DL. Gender and developmental differences in exercise beliefs among youth and prediction of their exercise behavior. Journal of School Health, 1995; 65: 213-219. https://doi.org/10.1111/j.1746-1561.1995.tb03365.x

34.Reynolds KD, Killen JD, Bryson S.W, Maron DJ, Taylor CB, Maccoby N, et al. Psychosocial predictors of physical activity in adolescents. Preventive Medicine, 1990; 19(5): 541-551. https://doi.org/10.1016/0091-7435(90)90052-L

35.Trost SG, Pate RR, Dowda M, Saunders R, Ward DS, Felton G. Gender differences in physical activity and determinants of physical activity in rural fifth grade children. Journal of School Health, 1996; 66: 145-150. https://doi.org/10.1111/j.1746-1561.1996.tb08235.x

36.Zakarian JM, Hovell MF, Hofstetter CR, Sallis JF, Keating KJ. Correlates of vigorous exercise in a predominantly low SES and minority high school population. Preventive Medicine, 1994; 23: 314-321. https://doi.org/10.1006/pmed.1994.1044

37.Van KDH, Paw MJ, Twisk JW, Van MW. A brief review on correlates of physical activity and sedentariness in youth. Medicine Science in Sport Exercise, 2007; 3(9): 1241-1250.

38.Sallis JF, Prochaska JJ, Taylor WC. A review of correlates of physical activity of children and adolescents. Medicine Science in Sport Exercise, 2000; 32(5): 963-975. https://doi.org/10.1097/00005768-200005000-00014

39. Wu T, Pender N. Determinants of physical activity among Taiwanese adolescents: an application of the health promotion model. Research in Nursing Health, 2002; 25: 25-36. https://doi.org/10.1002/nur.10021

40.Ryan GJ, Dzewaltowski DA. Comparing the relationship between different types of self-efficacy and physical activity in youth. Health Education Behavior, 2002; 29(4): 491-504. https://doi.org/10.1177/109019810202900408

41.Kowalski KC. Crocker PRE, Donen RM. The Physical Activity Questionnaire for Older Children (PAQ-C) and Adolescents (PAQ-A) Manual. College of Kinesiology University of Saskatchewan; 2004.

42.Sert Z.E. Temel AB. Adaptation of physical activity questionnaire for primary school students to Turkish society: the study of validity and reliability. DEUHYO ED, 2014; 7(2): 109-114.

43.Saygın Ö, Göral K, Bingöl E, Ceylan Hİ. Turkish adaptation of the physical activity efficacy scale: the study of validity and reliability. Uluslararast Spor, Egzersiz ve Antrenman Bilimi Dergisi. 2017; 3(2): 44-54. https://doi.org/10.18826/useeabd.308845

44.Tabachnick B.G, Fidell LS. Using Multivariate Statistics (sixth ed.) Pearson, Boston: US.; 2013.

45.Feltz DL, Magyar TM. Self-efficacy beliefs of adolescents. In: F. Pajares TC. Urdan (Eds.), Self-efficacy beliefs and adolescent development and education. Greenwich, CT: Information Age Publishing; 2006. P. 139-160.

46. Gao Z, Lochbaum M, Podlog L. Self-efficacy as a mediator of children's achievement motivation and in class physical activity. Perceptual and Motor Skills. 2011; 113(3): 969-981. https://doi.org/10.2466/06.11.25.PMS.113.6.969-981

47.Su X, Ping X, McBride RE, Liu J, Thornton MA. AtRisk Boys' Social Self-Efficacy and Physical Activity Self-Efficacy in a Summer Sports Camp. Journal of Teaching in Physical Education, 2016; 35: 159 -168. https://doi.org/10.1123/jtpe.2014-0176

48.Keskin N, Öncü E, Küçük Kılıç S. Attitudes and self-efficacy of middle school students toward physical education classes. Ankara Universitesi Spor Bilimleri Dergisi, 2016;14 (1): 93107.

49.Reigal R, Videra A, Gil J. Physical exercise, general efficacy and life satisfaction in adolescence. Revista International Journal of Medicine and Science of Physical Activity and Health, 2014; 14(55): 561-576.

50.Cengiz C, T1lmac K. High School Students' Exercise-Related Stages of Change and Physical Activity Self-Efficacy. Eurasian Journal of Educational Research. 2018;73: 59-76. https://doi.org/10.14689/ejer.2018.73.4

51.Hutchins M, Drolet JC, Ogletree RJ. Physical Activity Patterns and Self-Efficacy of Selected College Students. The Health Educator. 2010; 42 (2): 84-89.

52.Janssen I, Leblanc GA. Systematic review of the health benefits of physical activity and fitness in school-aged children and youth. International Journal of Behavioral Nutrition and Physical Activity, 2010; 7(40): 1-16. https://doi.org/10.1186/1479-5868-7-40

53.Lee IM, Shiroma EJ, Lobelo F, Puska P, Blair SN, Katzmarzyk P, Group LP. Effect of physical inactivity on major noncommunicable diseases worldwide: an analysis of burden of disease and life expectancy. Lancet, 2012; 219-229. https://doi.org/10.1016/S0140-6736(12)61031-9

54.Loprinzi P, Cardinal B, Loprinzi K, Lee H. Benefits and environmental determinants of physical activity in children and adolescents. Obesity Facts, 2012; 597-610. https://doi.org/10.1159/000342684

55.Craigie A, Matthews, J, Rugg-Gunn A, Lake A, Mathers J, Adamson A. Raised adolescent body mass index predicts the development ofadiposity and acentraldistribution ofbody fat in adulthood:Alongitudinal study. Obesity Facts, 2009;150-156. https://doi.org/10.1159/000218092

56.Ishii K, Shibata A, Adachi M, Nonoue K, Oka K. Gender and grade differences in objectively measured physical activity and sedentary behavior patterns among Japanese children and adolescents: a cross-sectional study. BMC Public Health [Internet]. 2015 Dec [cited 2019 Mar 15];15(1). Available from: http://www.biomedcentral.com/1471-2458/15/1254 https://doi.org/10.1186/s12889-015-2607-3

57.Kettner S, Kobel S, Fischbach N, Drenowatz C, Dreyhaupt $\mathrm{J}$, Wirt $\mathrm{T}$, et al. Objectively determined physical activity levels of primary school children in south-west Germany. BMC Public Health [Internet]. 2013 Dec [cited 2019 Mar 15];13(1). Available from: http://bmcpublichealth. biomedcentral.com/articles/10.1186/1471-2458-13-895 https://doi.org/10.1186/1471-2458-13-895

58.Chaput JP, Lambert M, Mathieu ME, Tremblay MS, O' Loughlin J, Tremblay A. Physical activity vs. sedentary time: independent associations with adiposity in children. Pediatr Obes. 2012; 7(3):251-8. https://doi.org/10.1111/j.2047-6310.2011.00028.x

59.Edwardson CL, Gorely T, Pearson N, Atkin AJ. Sources of Activity-Related Social Support and Adolescents' Objectively Measured After School and Weekend Physical Activity: Gender and Age Differences. J Phys Act Health. 2012; 1153-1158

60.Cairney J, Kwan MY, Velduizen S, Hay J, Bray SR, 
Faught BE. Gender, perceived competence and the enjoyment of physical education in children: a longitudinal examination. Int J Behav Nutr Phys Act. 2012; 9: 26. https://doi.org/10.1186/1479-5868-9-26

61. Wickel EE, Eisenmann JC, Welk GJ. Maturity-related variation in moderate-to-vigorous physical activity among 9-14 year olds. J Phys Act Health. 2009; 6: 597-605. https://doi.org/10.1123/jpah.6.5.597

62.TMH (Turkey Ministry of Health) Turkey Nutrition and Health Research 2010: Assessment of Nutritional Status and Habits Results Report. Ankara: Ministry of Health, General Directorate of Health Research; 2014.

63. Ward JS, Duncan SJ, Jarden A, Stewart T. The impact of children's exposure to green space on physical activity, cognitive development, emotional wellbeing, and ability to appraise risk. Health Place, 2016; 40: 44-50. https://doi.org/10.1016/j.healthplace.2016.04.015

64.Ivashchenko O, Khudolii O, Iermakov S, Bartik P, Prykhodko V. Movement Coordination: Identification of Development Peculiarities in Girls and Boys Aged 11-13. Teoriâ Ta Metodika Fìzičnogo Vihovannâ, 2018;18(3):136-147. https://doi.org/10.17309/tmfv.2018.3.04

65.Ivashchenko O, Khudolii O, Iermakov S, Prykhodko V, Cieslicka M. Movement Coordination: Identification of AgeRelated Dynamics of its Development in Girls Aged 11-13. Teoriâ Ta Metodika Fìzičnogo Vihovannâ, 2018;18(2):93-99. https://doi.org/10.17309/tmfv.2018.2.06

66.Doroshenko EY, Svatyev AV, Iermakov SS, Jagiello W. The use of cardio training facilities in training 7-9-year-old judo athletes. Archives of Budo Science of Martial Arts and Extreme Sports. 2017;13:165-72.

\section{Information about the author:}

Alpkaya U.; http://orcid.org/0000-0002-5574-6737; ualpkaya@marmara.edu.tr; Faculty of Sport Sciences, Physical Education and Sport Teaching, Marmara University, İstanbul; Marmara University, Anadolu Hisari Campus 34810, Beykoz - Istanbul, Turkey.

Cite this article as:

Alpkaya U. The relationship between the physical activity efficacy and physical activity of the middle school students. Pedagogics, psychology, medical-biological problems of physical training and sports, 2019;23(2):59-65. https://doi.org/10.15561/18189172.2019.0202

The electronic version of this article is the complete one and can be found online at: https://www.sportpedagogy.org.ua/index.php/PPS/issue/archive

This is an Open Access article distributed under the terms of the Creative Commons Attribution License, which permits unrestricted use, distribution, and reproduction in any medium, provided the original work is properly cited (http://creativecommons.org/licenses/by/4.0/deed.en).

Received: 04.03.2019

Accepted: 02.04.2019; Published: 30.04.2019 